schemes may be attended by considerable risks that are often overlooked until too late.

It is argued that small improvements may prove to be sounder investments than grandiose schemes, and that the latter, if adopted, should always be tested by experimental pilot projects prior to any wide implementation.

\section{References}

Cloudlsey-Thompson, John L. (1970). Animal utilization. Pp. 57-72 in Arid Lands in Transition (Ed. H. E. Dregne). Amer. Ass. Adv. Sci., Washington, D.C.: xiii + 524 pp., illustr.

CloudLsey-Thompson, John L. (1974). The expanding Sahara. Environmental Conservation, 1(1) pp. 5-13, 7 figs.

Cloudsley-Thompson, John L. (1975a). Desert expansion and the adaptive problems of the inhabitants. Pp 255-68 in Environmental Physiology of Desert Organisms (Ed. N. F. Hadley). Dowden, Hutchinson \& Ross, Stroudsberg, Pennsylvania: viii $+283 \mathrm{pp}$., illustr.

Cloudscey-Thompson, John L. $(1975 b)$. Developments in the Sudan parks. Oryx, 12, pp. 49-52.
Cloudsley-Thompson, John L. (1977). Man and the Biology of Arid Zones. Edward Arnold, London: xi +182 pp., illustr.

Cloudsley-Thompson, John L. (in press). [Review.] Biological Conservation.

KASSAS, M. (1972). Ecological consequences of water development projects. Pp. 215-35 and discussion to p. 246 in The Environmental Future (Ed. Nicholas Polunin). Macmillan, London \& Basingstoke, and Barnes \& Noble, New York: xiv +660 pp., illustr.

Rapp, A., Le Houérou, H. N. \& Lundholm, B. (Eds) (1976). Can Desert Encroachment Be Stopped? A Study with Emphasis on Africa. (Ecological Bulletins No. 24.) United Nations Environment Programme and Secretariat for International Ecology, Stockholm: 241 pp., illustr.

Thompson K., (1976). Swamp development in the head waters of the White Nile. Pp 177-96 in The Nile, Biology of an Ancient River (Ed. J. Rzóska). Monographiae Biol., 29, Junk, The Hague: xix +417 pp.

Tinker, Jon (1977). Sudan challenges the sand-dragon. New Scientist, 73, pp. 448-50.

WRIGHT, Pearce (1977). Pouring in Arab millions to reclaim the desert. The Times (London), February 22nd.

\title{
International Union for Conservation of Nature and Natural Resources (IUCN) : *
}

\section{A Dynamic Strategy}

Impressive steps have been taken to place the finances and the administration of IUCN on a firm footing-involving measures that are absolutely essential to provide the solid framework in which the real work of the Union can develop. Yet however important these steps may be, IUCN does not exist to provide the world with a model of good administration and financial management so much as to promote world conservation, and it is by its success in this field that it will be judged by its members and by the world outside.

This is not the place or time to present any new philosophy of conservation or to justify our cause. Rather is it my task simply to present to you what has been accomplished according to the mandate that was given to us at the last General Assembly, held in 1975 in Kinshasa, Zaire, $\dagger$ and it is my great honour and pleasure to do so.

At previous General Assemblies there has been frequent reference to the 'Programme' of IUCN. We suggest now that we should use the word 'Strategy' for the grand design and 'programme' for its component parts-e.g. the Marine Programme, the South-East Asian Programme, and so on. At Kinshasa $\dagger$ it was decided that the role of IUCN should be to design strategies for action, and to act as a stimulus and a catalyst. There was also a favouring of the principle of concentration of effort-on a region, or a country, or a topic. We have tried to act in this way and those recommendations have proved to be both practicable and wise, allowing us to make the best use of small resources and a small staff.

Our output, the result of our endeavours, is effective conservation action, towards which an important concern is cost-effectiveness-to accomplish as much real conservation as possible with the lowest sufficiency of expenditure. We have given much consideration in the last year to the ways in which a small organization such as IUCN can best do this, in a sphere in which other large and influential

\footnotetext{
* Substance of the opening speech by the Acting DirectorGeneral at the Extraordinary General Assembly of IUCN, held in Geneva, Switzerland, during 19-21 April 1977-see the report on page 154 of this issue.-Ed.

† See 'I.U.C.N. Programmefor the Triennium 1976-78', published in Environmental Conservation, Vol. 2, No. 4, pp. 305-9, 1975.
}

organizations are also operating-most notably UNEP, FAO, and UNESCO. We have come to the conclusion that our proper role is to design the conservation strategy within which we and others should operate and, using our particular strength as an NGO which also has a significant number of State members, to stimulate Governments and other organizations to carry out their responsibilities for conservation broadly within the strategy that we have drawn up.

We must also be in the forefront in developing new ideas and concepts. This is now made possible because the objectives of IUCN largely coincide with those of the two organizations which provide us with substantial general support-UNEP, the pre-eminent United Nations agent in this field, and the World Wildlife Fund (WWF).

Now what does this conservation strategy consist of? IUCN is making surveys of the status of conservation throughout the world--region by region or subject by subject, whichever is more appropriate. Examples are South-East Asia as a region or the Marine Programme as a subject. Using consultants, our members, our Commissions, and all other available sources of information, we first determine what needs to be done, in terms of action priorities. We also assess what is practicable.

The next stage is to identify 'limiting factors'. Almost always one finds that there is something which blocks further progress - the lack of political will to act, inadequate national legislation, an unsuitable administration, too few trained staff, insufficient scientific information, or sometimes quite other things. It is on these limiting factors that we should concentrate, for it is they that hinder further advances, though circumvention with patient persistence is rarely impossible when the will remains.

The final questions to answer are how and who? Should the work be carried out by national governments, should it be supported by one of the big aid organizations (UNDP or the World Bank), should IUCN do it itself, is it appropriate for WWF funding? Correct answers to these questions will alone ensure that the scarce resources of money and manpower available for world conservation are used to the best advantage. 
I would like to emphasize a number of points:

Programmes of this kind take a long time to plan and develop. Forward thinking is essential; success depends on stability, consistent policy, and, where necessary, the patient persistence that we mentioned earlier.

We cannot, of course, carry out the basic review of world problems all at once. It is necessary to examine the regions and problems one by one in a planned sequence; and this is what we are doing. The process could be speeded up, but only if our resources were increased accordingly. I must also emphasize that a world strategy and action plan can never be complete and final. It must be continuously reviewed and revised. Some problems will, we hope, be solved; but more frequently as one kind of action is completed, other priorities will emerge. We should look upon the world conservation strategy, therefore, as a kind of register-which must be continually kept up to date-of priorities for action, backed by notes on practicability, the most effective approach, who might carry out the action, and how. But although priorities must change from time to time, fundamental changes of direction would destroy any impetus we may have gained.

After deciding on the most desirable and practicable strategy, the next and most important stage is, of course, to try and ensure that the action takes place. Here IUCN is developing a network of consultative mechanisms of which some are of particular importance. Thus the Ecosystem Conservation Group (UNEP, FAO, UNESCO, and IUCN) is being strengthened to ensure that action takes place within the broad strategies developed by UNEP; for this the work of FAO, UNESCO, and IUCN, should develop in concord and, we hope, along the lines which we have identified. The strategies developed by IUCN should form the blue-print for action in the conservation and management of ecosystems and in the conservation of species.

The close accord developed with WWF should ensure that WWF can support a well-integrated conservation programme which should appeal to those who provide money to it and will ensure that the funds available to WWF for international conservation are spent to the very best advantage. Another powerful spearhead for action should be the members of IUCN themselves. One of our must significant tasks must be to mobilize the full capacity of the members of IUCN, both governmental and non-governmental, to carry forward the strategy which we design.

Conservation is a unitary process. It depends equally on good science, a public that is educated and aware, good laws, good planning, and good administration. The aims and purposes of all the IUCN Commissions converge. For this reason I am proposing to all of them that they should devote much thought in the coming months to their role in relation to one another and to the programme as a whole, and that a meeting of all Commission Chairmen and ViceChairmen should be called in late 1977 or early 1978 to plan for the next decade.

One crucial problem is final implementation. We are identifying many more problems than there are international resources to implement. WWF does much, but funds within each country, international funds, and bilateral aid funds, will be needed on a much larger scale if our efforts are to bear fruit.

I would like to add something on a personal note. In this programme we have now begun to build a solid foundation for future action-without a solid foundation it is vain to try to build a solid structure. But what we have done is only a beginning. The Union is concerned with values more, I would say, even than with science. For science should be the servant and not the master of mankind. Our programme must be firmly based in realism, but it must move ahead with vision. We should be the architects of guided change (call it development if you will)-guided in the direction of the 'good life' as well as the material well-being of Man, but (and the 'but' is all-important) in such a way that the potential of the biosphere to support this good life is not diminished. In particular we need to pay much more attention to the ways in which conservation can become part of development plans founded on local social and economic realities.

This is the way IUCN should go, and is the way in which, with care and wisdom in the development of our programme, I firmly believe it can and will go.

DuNCAN PoORE, Acting Director-General
I.U.C.N.
I110 Morges
Switzerland.
I.U.C.N. Switzerland.

\section{Efforts Renewed to Improve Control of Trade in Endangered Species}

The World Wildlife Fund is making a new drive to get governments which have not so far acceded to the Convention un International Trade in Endangered Species of Wild f auna and Flora to do so as soon as possible.

So far 35 countries are parties to the Convention, which can $: \geqslant$ into force on 1 July 1975. They are Australia, Brazil, Cansda, Chile, Costa Rica, Cyprus, Ecuador, Finland, East Germany, West Germany, Ghana, India, Iran, Madagascar, Mauritius, Morocco, Nepal, Niger, Nigeria, Norway, Pakistan, Papua New Guinea, Paraguay, Peru, Seychelles, South Africa, Sweden, Switzerland, Tunisia, Union of Soviet Socialist Republics, United Arab Emirates, the United Kingdom, United States of America, Uruguay, and Zaïre.

Although representations have been made before, the World Wildlife Fund is now making renewed efforts to broaden international acceptance of the Convention, which is zonsidered one of the key methods of stopping the dangercus drain on threatened plants and animals through comimercial activities-quite apart from excessive hunting, collection, and the effects of pollution and other results of human population-pressures. Countries are being asked to accede as soon as possible, and meanwhile to act in the spirit of the Convention.

The Convention attempts to control the situation by imposing a virtual ban on trade in the most endangered species, including Tiger, Asiatic Lion, Leopard, Snow Leopard, Gorilla, Orang-utan, rhinoceroses, Asiatic Elephant, White-tailed, Bald and Imperial Eagles, Peregrine Falcon, crocodiles, and most orchids. In addition, approved export and import permits are required for all international movements of these species or parts of them.

A second list covers species which could become endangered unless trade is carefully monitored. This list includes all cats, otters, monkeys, and eagles not in the first list, African Elephant, all fur seals, Red-breasted Goose, Great Indian Hornbill, and a number of birdwing butterflies. Approved export permits are required which ensure close watching of the trade.

A third list contains species which countries protect locally and for which they need the cooperation of other governments to reinforce their domestic legislation.

It is considered of crucial importance for all members of the European Economic Community and Japan to accept the Convention because they are major importers. Among the nine nations of the European Economic Community (EEC), only Britain and West Germany have so far become parties.

PETER F. R. JACKSON, Director of Information World Wildlife Fund 1110 Morges Switzerland. 